\title{
APPLICATION OF MATRIX IMPORTANCE-PERFORMANCE IN THE MAINTENANCE SECTOR OF AN HIGHER EDUCATION INSTITUTION
}

Lenize Danette de Oliveira FACCAT, Brazil

E-mail: lenizedanette@gmail.com

Jéssica da Silva Haubert FACCAT, Brazil E-mail: jessica-haubert@hotmail.com

Alexandre Sakis FACCAT, Brazil E-mail: alexandre-xandre@hotmail.com

Cleimar da Silva Machado

FACCAT, Brazil E-mail: cleimar@sou.faccat.br

Bruno Miranda Dos Santos FACCAT, Brazil E-mail: brmiranda10@gmail.com

Submission: 7/31/2019 Accept: 10/1/2019

\section{ABSTRACT}

The sector service is what has the highest employability index in the country and is even the one with the largest participation in the world economy. In this sense, there is evidence of increased awareness of organizations that improvement has to come from the inside out. Thus, this research aims to demonstrate the competitive importance of the maintenance sector of a Higher Education Institution (HEI) through the application of the importance-performance matrix. As for the methodological procedures, this study is characterized by exploratory and quantitative research. A set of criteria to be evaluated within the organizational performance objectives was created in conjunction with maintenance staff and an IES strategic sector manager. As a result, an HEI demonstrated good performance in most of the criteria, generated an exception of one of the criteria that was out in the areas that need improvement actions, the accomplishment of the results by the matrix is important. 
DOI: 10.14807/ijmp.v11i3.1108

Keywords: Matrix Importance-performance, service sector, competitiveness, organizational performance

\section{INTRODUCTION}

Physical structures and facilities are important parts of any organization, and they directly or indirectly a strong relationship with the quality of products or services (Silva, 2016). The properly structured maintenance sector is fundamental to the evolution and competitiveness of an educational institution (SILVA, 2016).

Institutions of higher education have grown over the years and have become increasingly part of global networks (WAKCHAURE et al., 2006). All of these modernizations in the service delivery environment have put the aspects of the maintenance industry in focus on developing more efficient and effective operations. Manufacturing maintenance deals with highly industrial equipment that requires extraordinary types of knowledge with limited options from technology providers (PHOGAT; GUPTA, 2018). In this context, this article aims to demonstrate the competitive importance of the maintenance sector of an educational institution through the application of the matrix importance-performance.

There is a wide variety of types of university institutions. These, as to its administration, can be classified as public (municipal, state or federal) or private, which naturally influences the way in which they are managed (LENNAN et al., 2014). In this article, the educational institution object of this research is private. The maintenance strategy of this type of institution is very similar to manufacturing operations, both of which employ processes that add value to the basic input used to create the final product (PHOGAT; GUPTA, 2018).

Recent studies about the strategic management approach in higher education institutions (HEI) report several benefits to the organization. Lennan et al. (2014) identified opportunities for HEIs to progress towards strategic corporate social responsibility practices. Castro et al. (2015) verified how strategic planning occurs in a philanthropic HEI. The findings indicated that planning occurs as the theoretical definitions of the school management and administration area.

Araújo et al. (2017) demonstrated that one of the main motivations for adopting the strategic management process in HEIs in the state of Ceará was to increase competitiveness and highlight the use of new information technologies. Miranda et al. (2017) analyzed motivational factors that influence the performance of activities in an HEI. 
DOI: 10.14807/ijmp.v11i3.1108

They concluded that, above all, the leadership factor is a differential to obtain a good performance in the work environment. It should be noted, however, that studies that consider specific sectors of HEI as a center of strategic actions, such as the maintenance sector considered in this research, were not found, therefore, it is an important justification for the development of this work.

The use of strategic planning as an instrument of competitive differentiation has proved to be efficient, given that organizational development is linked to the capacity of managers to formulate, implement and monitor strategies (MINTZBERG et al., 2006). However, for Araújo et al. (2017), although there has been growing interest in strategic management in HEIs, this is a subject that has not yet been explored.

This article is structured in five sections. Section 2 presents a review of the specific literature of the strategic management tool used in this research and the context in which it was implemented. Section 3 presents the process of methodological development. Section 4 presents the results obtained. Finally, section 5 presents the conclusion and suggestions for future work.

\section{REVIEW OF THE LITERATURE}

\subsection{Matrix of Importance-Performance}

A matrix importance-performance is a tool present in the context of the administration of the production of goods and services, usually used to evaluate the performance of a product or a production process (SLACK et al., 1997). The matrix is built from the level of importance and performance level of competitive criteria associated with the products. The competitive criteria can be of the type: speed and reliability in the delivery of the products; flexibility in the design or mix of product production and reduced cost of manufactured goods (MIRANDA et al., 2016).

The level of importance can be determined by classifying the criteria into qualifiers and order winners (HILL, 1993). The qualifying levels represent a certain minimum score required to compete in the market. The order-winning levels are those on which the customer is based to choose their suppliers (MIRANDA et al., 2016). These two classifications can be added to the less important levels that are neither qualifies nor winners of orders, and do not influence customers significantly.

In the understanding of Betto, Ferreira and Talamini (2010), the matrix construction technique allows the identification of four zones of improvement priority. The method consists 
DOI: 10.14807/ijmp.v11i3.1108

of placing the ordered pairs, formed by the mean scores of the importance and performance responses of each attribute (PEREIRA et al., 2013). The level of performance can be judged on the basis of being better, equal or worse than the market. This matrix can be divided into four breeding priority regions as shown in Figure 1.

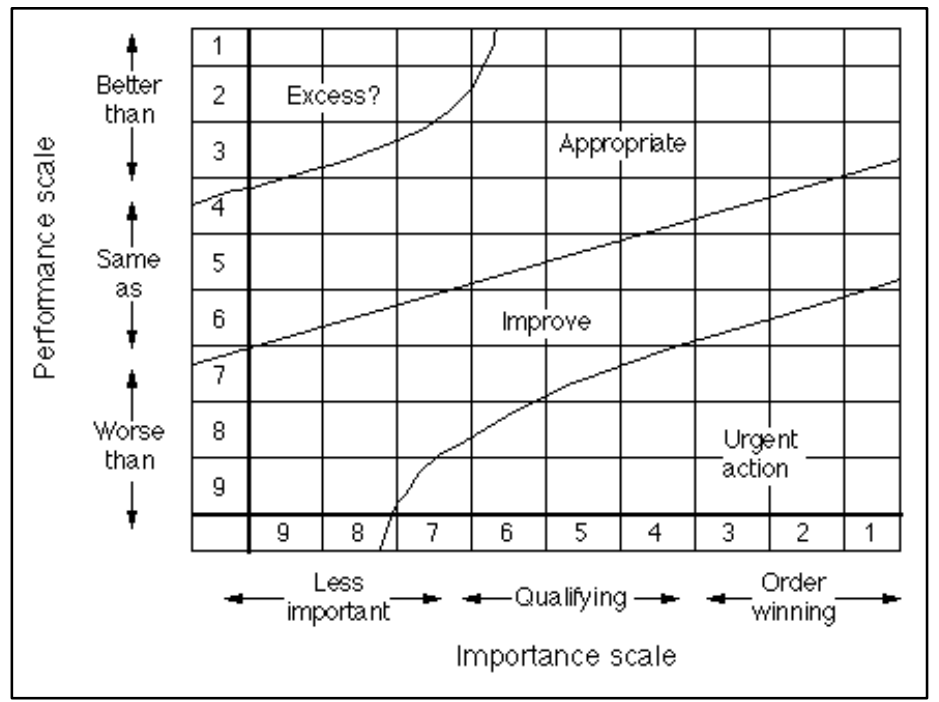

Figure 1: Matrix of Importance-Performance Source: Adapted from Slack (1994)

The appropriate region is separated at its lower edge by the acceptability boundary, which is the company's minimum level of performance tolerable by the market. Any competitive criteria that fall in the breeding region is a candidate to be improved, but if it is in the lower-left corner of the matrix, it may be a non-urgent improvement case. The most critical situation is when a competitive criterion is in the region of urgent action, demanding, in the short term, the implementation of improvement plans (DOS SANTOS et al., 2018).

Finally, there is also the region of excess where the performance achieved is greater than necessary. In that case, part of the resources could be allocated to improving the criteria in the region of urgent action. In addition to the evaluation of productive processes, the matrix importance-performance can be used to measure process performance in service providers (GIANESI; CORRÊA, 1996).

\subsection{Maintenance management}

With the advancement of technology and the increasing demands for productive plants without $\mathrm{s}$ failure is impossible to manage the maintenance without the aid of instruments of control and management, according to Silva (2016), the integration of people, places, processes and technology is of utmost importance in a maintenance and conservation system to guarantee the functionalities of structures and installations. 
INDEPENDENT JOURNAL OF MANAGEMENT \& PRODUCTION (IJM\&P)

http://www.ijmp.jor.br

v. 11, n. 3, May-June 2020

ISSN: $2236-269 X$

DOI: 10.14807/ijmp.v11i3.1108

The strategy of maintenance function for organizations is advocated by several authors. Wireman (1998) shows that the maintenance policy of a company reflects in a determinant factor of the success of the planning of the production and, therefore, of the productivity of the process. Souris (1992) argues that the search for quality of process and product passes through the effectiveness of maintenance, without which investment in the quality management systems can be entirely lost. Although these studies were developed in the 1990s, studies that deal with maintenance management use very similar concepts recently.

Due to increased competition among higher education organizations, the maintenance sector emerges as an area that can bring benefits to the institution if it is considered as part of the organization's strategies. According to Queiroz (2015), the well-designed maintenance function can ensure the availability of the equipment and its facilities. Good maintenance management contributes actively to business excellence (KARDEC, 2001).

Corroborating with this, Fuentes (2006) says that "investments in maintenance tend to grow in all economic sectors of our society." With the technological advances, the maintenance guarantees its space, as there is a continuous growth of the capital goods and tied to this the demands of the greater reliability of the installations, which imposes that the management of the maintenance must have procedures described and reliable.

The national survey of the Brazilian Association of Maintenance and Asset Management (ABRAMAN) conducted in 2011 shows a series of data that portrays the national panorama of maintenance management. The research was highlighted in aspects such as the educational training of professionals and the results of maintenance presented through indicators such as Operational Availability and Unavailability. Besides these, the research approaches with more emphasis the values relative to the Costs of maintenance.

Some of the success factors for maintenance management, considering the qualification of good or bad management according to the results obtained in them, are the organizational structure of maintenance; costs of the sector; qualification of staff; outsourcing policy and use of quality tools for failure analysis (VIANA; RIBEIRO, 2017).

\subsubsection{Corrective maintenance}

According to Kardec and Nascif (2009, p. 38), "Corrective maintenance is the action to correct the failure or the performance smaller than expected". For the Brazilian Association of Technical Standards (1994), corrective maintenance is "maintenance performed after the 
DOI: 10.14807/ijmp.v11i3.1108

occurrence of a stop intended to reallocate an item in conditions to perform a required function".

Therefore, this maintenance method should not be classified as an emergency maintenance method, it acts mainly when poor performance occurs or a component fails (KARDEC; NASCIF, 2009). In this way, the main function of corrective maintenance is to correct or restore the operating conditions of the equipment or system. Corrective maintenance can be divided into Unplanned corrective maintenance and Planned corrective maintenance.

According to Lima (2016), this type of maintenance is the most used in Brazil, due to our culture of only performing the interventions when the elements and/or equipment is already in an advanced state of deterioration. With this, the costs with this type of activity tend to be much higher than those carried out preventively.

The author also points out that it is impossible to eliminate this form of maintenance since at some point in time the system will reach its projected useful life and will require a greater investment in order to significantly recover its performance. The analysis of maintenance costs developed by Almeida (2005) indicates that a repair performed by corrective-reactive mode will have a cost three times higher than when the same repair is done in a programmed or preventive way.

\subsubsection{Preventive maintenance}

According to Kardec and Nascif (2009, p.42), preventive maintenance "is the performance performed in a way to reduce or avoid failure, according to a previously elaborated plan based on defined intervals of time". For the Brazilian Association of Technical Standards (1994) preventive maintenance is "maintenance performed at predetermined intervals, or according to prescribed criteria, designed to reduce the probability of failure or degradation of an item's operation."

This maintenance method seeks to prevent the occurrence of failures and is generally imperative in systems where safety is the most relevant factor (KARDEC; NASCIF , 2009). Xenos (2012) introduces the idea that preventive maintenance is one of the main activities in a company, encompassing inspections, part changes and reforms.

For Santos (2010, p.18), preventive maintenance "consists of exercising control over the equipment in order to reduce the probability of failure based on regular maintenance intervals." For Castilhos (2002), preventive maintenance is based on the balanced distribution of workload, rationalization of spare parts stock, maintaining maximum availability of 
INDEPENDENT JOURNAL OF MANAGEMENT \& PRODUCTION (IJM\&P)

http://www.ijmp.jor.br

v. 11, n. 3, May-June 2020

ISSN: $2236-269 X$

DOI: 10.14807/ijmp.v11i3.1108

machines and equipment, eliminating improvisation, eliminating or easing delays in order to increase production, replacing problematic parts immediately, so that the rest are preserved, reduction of costs, maintenance of product quality, preservation of the environment, reduction of accidents at work and increase the useful life of equipment.

\subsubsection{Predictive Maintenance}

For the Brazilian Association of Technical Standards (1994), predictive maintenance is the "systematic application of analysis techniques, using centralized or sampling means to reduce corrective and preventive maintenance." According to Nasa (2008) predictive maintenance mainly uses non-intrusive methods, test techniques, visual inspection and performance data to evaluate the condition of machines and modify maintenance tasks arbitrarily programmed. Continuous equipment analysis and condition monitoring data enable planning and scheduling of maintenance or repairs to avoid possible catastrophic and functional failures.

According to Castilhos (2002, p. 30), predictive maintenance "is an improvement of preventive maintenance, based on the actual knowledge of the conditions of the machine, equipment or component".

\section{METHODOLOGY}

The study was carried out with the purpose of planning and structuring the maintenance and conservation sector of private HEIs, located in the Rio Grande do Sul, with a physical structure of 10,000 square meters of constructed area and 8 hectares of the total territory. In 1977 it became autonomous with the recognition of the courses of Administration and Accounting Sciences, and due to the increase in the number of students there was a need to open a proper campus to accommodate the administrative sector of the institution and to house (shelter), then existing and future courses, this occurred in 1999. With the constant growth of the activities of maintenance and conservation of the physical areas, it was justified to implement maintenance methods increasingly critical and careful so that it does not harm the end-of-premises activity.

This study is characterized as exploratory and quantitative research. According to Gil (1999), quantitative research translates opinions and information into numbers to classify and analyze them using statistical techniques. The following are the stages of realization:

1) Choice of the company: In meetings held in a group, a higher education institution was chosen, and from that, we delimited the study to a specific sector, the maintenance 
DOI: 10.14807/ijmp.v11i3.1108

sector, as this presents a potential contribution to the development of strategies for the organization.

2) Theoretical basis: the theoretical basis comes mainly from articles that deal with the issue of strategic management and management tools.

3) Elaboration of the questionnaires: together with the employees of the maintenance sector, six evaluation criteria were defined for the sector in terms of importance for the clients and to analyze the current position against the competition. It was used in the questionnaire the basis of the scale proposed by Slack (1977), where respondents should score a note 1-9 first about the importance of the criteria for the customer and subsequently in relation to the performance of HEI, and the criteria created are the result of the unfolding of the five performance objectives.

4) Application of the questionnaires: Ten questionnaires of both importance and performance were applied to the maintenance sector. Regarding the profile of the interviewees, five carry out administrative functions and the other five are part of the operational.

5) Data analysis: With the use of Microsoft Excel, the data were tabulated obtaining the mean of importance and performance for each criterion.

6) Construction of the matrix: Again with the help of Microsoft Excel and using the means of the importance of the criteria for the customers and performance of the institution was possible to build the matrix.

The maintenance of the campus counts with the twenty-seven employees distributed in several independent and interconnected sectors under the management of a Manager. To make communication more efficient and to facilitate the execution of routine activities, there is a need to implement maintenance management and control systems with the highest possible clarity and communicability, so that all activities are within the desired standards.

\section{RESULTS AND DISCUSSION}

The application of the importance-performance matrix was performed in the maintenance sector, which has 27 employees and is of paramount importance for the operation of the HEI. From this, in order to better identify the most important criteria, six criteria were formulated to be evaluated within the five performance objectives proposed by Slack et al. (1977). Table 1 presents the evaluation criteria that have been defined. 
DOI: 10.14807/ijmp.v11i3.1108

Table 1: Objectives and items evaluated in the Maintenance sector

\begin{tabular}{|l|l|}
\hline Objectives & Evaluated items \\
\hline \multirow{2}{*}{ Quality } & Employee Service \\
\cline { 2 - 2 } velocity & Sector Organization \\
\hline Reliability & $\begin{array}{l}\text { Safety of products and services } \\
\text { provided }\end{array}$ \\
\hline Flexibility & $\begin{array}{l}\text { From accepting schedule changes to } \\
\text { adapt to any changes }\end{array}$ \\
\hline Cost & Product Price \\
\hline
\end{tabular}

The six evaluation criteria were prepared in conjunction with maintenance staff and a strategic sector manager from HEI. The criteria include, from the perspective of the maintenance sector, points that require greater attention and, if well developed, can contribute to the HEI achieve the strategic objectives.

\subsection{Matrix Analysis Importance - Performance}

After the collection of the data, the process of analysis of the information obtained for the construction of the matrix importance-performance. Table 2 presents the averages obtained in the application of the questionnaires.

Table 2: Averages of item evaluations

\begin{tabular}{|c|c|c|c|}
\hline Criteria & Importance & $\begin{array}{c}\text { Performance of } \\
\text { the institution } \\
\text { (A) }\end{array}$ & $\begin{array}{c}\text { Performance of } \\
\text { competition (B) }\end{array}$ \\
\hline Customer Service & 8.30 & 9.60 & 8.00 \\
\hline Industry organization & 9.00 & 8.10 & 8.00 \\
\hline Speed in execution & 8.50 & 7.90 & 8.00 \\
\hline $\begin{array}{c}\text { Safety of products and } \\
\text { services provided }\end{array}$ & 7.95 & 8.00 & 8.00 \\
\hline $\begin{array}{c}\text { To accept modifications } \\
\text { to the schedule, to adapt } \\
\text { to some change }\end{array}$ & 7.00 & 6.50 & 8.00 \\
\hline Product Price & 7.10 & 6.70 & \\
\hline \multicolumn{2}{|c|}{ Source: Authors (2018) } \\
\hline
\end{tabular}

Table 3 was based on the average of the scores from 1 to 9 given by the people that make use of the service of the maintenance sector of the HEI. And due to the lack of data and articles on this sector in other educational institutions, it was considered an average value of 8 for the competition.

Figure 1 shows the values of the competitors and the values of the company studied, it is necessary to transform the two values of performance into only one value that represents in 
DOI: 10.14807/ijmp.v11i3.1108

a coherent way the real performance of the institution in relation to the main competitors. Therefore, we calculated the difference between both institution and competition, and again we had to turn into grades 1 through 9 to apply the matrix correctly. For this purpose, a comparative scale was created to scale matrix, such range is shown in Table 3.

Table 3: Comparative scale equivalent to the scale of Slack et al (2009)

\begin{tabular}{|c|c|c|c|c|}
\hline \multicolumn{2}{|c|}{ Proposed Scale by Slack } & \multicolumn{3}{c|}{ Escala Equivalente } \\
\hline Considerably better than the best & 9 & 4 & $\begin{array}{c}\text { Considerably better than the } \\
\text { best }\end{array}$ \\
\hline Clearly better than the best & 8 & 3 & Clearly better than the best \\
\hline Marginally better than the best & 7 & 2 & Marginally better than the best \\
\hline $\begin{array}{c}\text { Sometimes marginally better than } \\
\text { the best }\end{array}$ & 6 & 1 & $\begin{array}{c}\text { Sometimes marginally better } \\
\text { than the best }\end{array}$ \\
\hline About the same as most & 5 & 0 & About the same as most \\
\hline $\begin{array}{c}\text { Often at close range behind major } \\
\text { competitors }\end{array}$ & 4 & -1 & $\begin{array}{c}\text { Often at close range behind } \\
\text { major competitors }\end{array}$ \\
\hline $\begin{array}{c}\text { Usually marginally worse than most } \\
\text { major competitors }\end{array}$ & 3 & -2 & $\begin{array}{c}\text { Usually marginally worse than } \\
\text { most major competitors }\end{array}$ \\
\hline Usually worse than most & 2 & -3 & Usually worse than most \\
\hline Considerably worse than most & 1 & -4 & Considerably worse than most \\
\hline
\end{tabular}

Source: Authors (2018) adapted from Slack et al. (1977)

The equivalent method transforms the differences into grades 1 through 9. Considering the number zero equivalent to 5 in the matrix scale, it is possible to create relationships in the other grades. A value approximation column was created since differences represented by decimal numbers were obtained. Using the above method, the following results were obtained for each criterion evaluated, as shown in Table 4.

Table 4: Difference between performance and actual performance of the institution

\begin{tabular}{|c|c|c|c|c|}
\hline Criteria & Importance & Dif. (A-B) & Approximation & $\begin{array}{c}\text { Relative } \\
\text { Performance } \\
\end{array}$ \\
\hline Employee Service & 8,30 & 1,6 & 4 & 7 \\
\hline Sector Organization & 9,00 & 0,1 & & 5 \\
\hline Fast execution & 8,50 & $-0,1$ & & 5 \\
\hline $\begin{array}{l}\text { Safety of products and } \\
\text { services provided }\end{array}$ & 7,95 & 0 & & 5 \\
\hline Accept schedule changes & 7,00 & $-1,5$ & & 4 \\
\hline Product Price & 7,10 & $-1,3$ & & 4 \\
\hline
\end{tabular}

Source: A stores (2018)

The results obtained within the Importance- Performance matrix is demonstrated according to the resulting regions in Figure 2, which compares the importance of HEI in relation to performance, against the criteria raised. It is noted that the criterion "employee 
ISSN: 2236-269X

DOI: 10.14807/ijmp.v11i3.1108

service" obtained, based on the comparative scale used, actual performance equal to 7 and the importance of approximately 8.30, which corresponds to the matrix enhancement region.

The criteria "Industry Organization," "speed of execution" and "security of products and services," obtained actual performance equal to 5, which represents performance "approximately equal to most", and the last two criteria, and "accept changes to the schedule" and "price of products" the actual performance achieved was 4, which equals " Often a short distance behind major competitors".

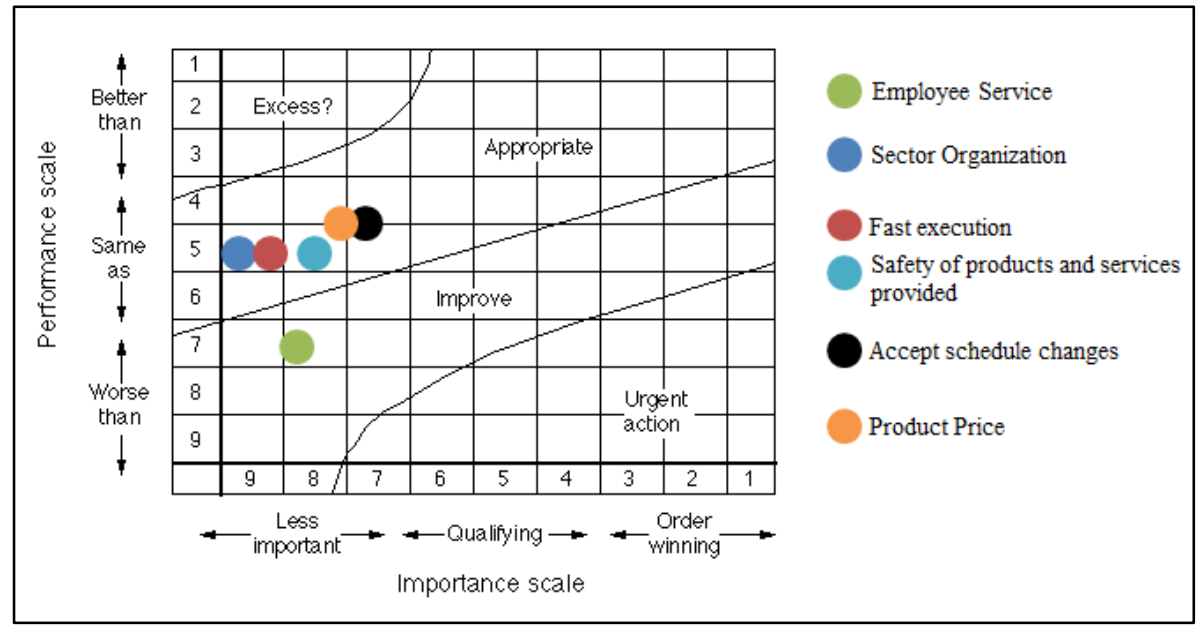

Figure 2: Comparative scale equivalent to the scale of Slack et al. (2009) Source: Authors (2018)

It is observed that the HEI needs to be proactive in developing initiatives to raise the performance of the criterion "employee attendance" since it is a factor with relative importance for the clients. According to the results obtained by Silva et al. (2018), quality in customer service is a key factor in the success of any business and it must be constantly improved.

According to the 14 principles of total quality (TQM), advocated by Deming as a managerial philosophy, the organization that provides a quality differential can be guided by these principles. According to Marshall and Kiser (2003), based on some of the items raised by Deming, the organization should concentrate its efforts on building quality from the outset, establishing regular training, instituting an education and improvement program (teamwork to support TQM culture).

The 14 points described are the basic principles of Deming's operational management theory and it is understood that TQM will only be operational when these elements become part of the organization's culture (MARSHAL; KISER, 2003).

The remaining of the evaluated criteria were positioned in the "adequate" quadrant, according to the results obtained. Regarding the competitors' analysis, it is concluded that the 
DOI: 10.14807/ijmp.v11i3.1108

manager should also research the functioning of other higher education institutions in the region, observe and evaluate the courses and advantages offered, the attendance characteristics, prices practiced, in other words, be attentive to the dynamism of this market segment in the education area to offer services that add value and stand out in an increasingly competitive market. The purpose of these managerial actions is to know the competitors and their customers, trying to identify what actions should be taken to improve the company's performance and ensure its continuity.

\section{CONCLUSION}

When analyzing the data, it was noticed that the adopted research method was adapted for the purpose of developing the objective initially proposed. The use of the Matrix Importance-performance allowed identifying the positioning of the clients against what they consider to be more relevant in the maintenance sector of a private HEI.

Through the matrix, it is also possible to visualize, what are the criteria that the managers of the HEI maintenance sector consider important to consider in order to improve quality in general and concentrate their efforts in order to provide quality services. In general, it was observed that the HEI sector performed well in most of the criteria, except for the criterion "employee attendance", which requires actions for improvement.

It is suggested that the maintenance sector of the HEI should develop actions to provide periodic training to employees since there is a reasonable turnover in this sector. In addition, although most of the criteria have been in the "appropriate" zone of the matrix, it is understood that all should be considered periodically in the improvement program of the HEI and the sector where the research was developed, since, based on the fundamentals TQM, continuous improvement of processes and operations must be a constant in any organization.

\section{ACKNOWLEDGMENTS}

We dedicate this work to the memory of colleague and friend Cleimar Machado.

\section{REFERENCES}

ALMEIDA, M. T. (2005) Manutenção Preditiva: confiabilidade e qualidade. In: https://www.mtaev.com.br/download/mntl.pdf, acesso em: 31/01/2019.

BRAZILIAN ASSOCIATION OF TECHNICAL STANDARDS. (1994). NBR 5462: Confiabilidade e Mantenabilidade. Rio de Janeiro.

BETTO, L.; FERREIRA, G. M. V.; TALAMINI, E. (2010) Aplicação da matriz importânciadesempenho no varejo de alimentos: um caso no Rio Grande do Sul. Revista da Micro e Pequena Empresa, v. 4, n. 2, p. 64. 
DOI: 10.14807/ijmp.v11i3.1108

CASTILHOS, J. S. (2002) Manutenção. Caxias do Sul: 2 ed.

ARAÚJO, F. J. A.; CABRAL, A. C. A.; DOS SANTOS, S. M.; PESSOA, M. N. M. (2018) Gestão estratégica em instituições privadas de ensino superior. Revista Gestão Universitária na América Latina-GUAL, v. 11, n. 1, p. 71-91.

DE CASTRO, A. B. C.; BRITO, L. M. P.; DOS SANTOS, R. S.; VARELA, J. H. S. (2015) O planejamento estratégico como ferramenta para a gestão escolar: Um estudo de caso em uma instituição de ensino filantrópica da Bahia/BA. HOLOS, v. 2, p. 195-211.

DOS SANTOS, T. S.; DA SILVA, E. V.; DA SILVA, L. A. A.; RIBEIRO, S. N.; DE SOUSA, S. C. (2018) A matriz importância-desempenho aplicada em um supermercado no município de marabá-pa. Revista Latino-Americana de Inovação e Engenharia de Produção, v. 6, n. 10, p. 27-45.

FUENTES, F. F. E. (2006) Metodologia para inovação da gestão de manutenção industrial. Dissertação de Doutorado. Programa de Pós-graduação de Engenharia Mecânica da Universidade Federal de Santa Catarina. Outubro.

GIANESI, I. N.; CORRÊA, H. L. (1996) Administração Estratégica de Serviços: operações para a satisfação dos clientes. São Paulo: Atlas.

HILL, T. (1995) Manufacturing strategy: text and cases. Macmillan International Higher Education.

KARDEC, A. (2009) Manutenção: função estratégica. Alan Kardec, Júlio Nascif.-3 ed. Ver. E ampl. - Rio de Janeiro : Qualitymark : Petrobras.

KARDEC, A.; RIBEIRO, H. (2002) Gestão estratégica e manutenção autônoma. Rio de Janeiro: ABRAMAN.

LEI N ${ }^{\circ}$ 13.589, DE 4 DE JANEIRO DE 2018.

http://www.planalto.gov.br/ccivil_03/_ato2015-2018/2018/lei/113589.htm Access:

$03 / 11 / 2018$ as $16: 17$

LIMA, D. J. N. (2016) A manutenção na conservação do bom desempenho das edificações ao longo de sua vida útil. (Bachelor's thesis, Universidade Federal do Rio Grande do Norte).

MAC LENNAN, M. L. F.; SEMENSATO, B. I.; OLIVA, F. L. (2015) Responsabilidade Social Empresarial: classificação das instituições de ensino superior em reativas ou estratégicas sob a ótica da governança corporativa. REGE-Revista de Gestão, v. 22, n. 4, p. 457-472.

MARSHALL, I. J.; KISER, L. (2003) Gestão da qualidade. 1 ed. Rio de Janeiro: Editora FGV.

MIRANDA, B. S.; PIETROBELLI, W.; PRATO NETO, C.; MORO, M.; SAGRILLO, M.; ANDRADE, D. F. D. (2017) A motivação como fator no desempenho em serviços públicos: um estudo de caso em um instituto de ensino superior. XVII Colóquio Internacional de Gestão Universitária. Mar del Plata, Argentina.

PEREIRA, E.; CAMPOS, D.; DANTAS, M. (2013) Desenvolvimento de uma escala para mensurar a qualidade do serviço no segmento de academias de ginástica. Anais do XXXIII Encontro Nacional de Engenharia de Produção - ENEGEP, p. 1-15, Salvador, BA.

PHOGAT, S.; GUPTA, A. K. (2018) Análise teórica de elementos JIT para implementação no setor de manutenção de indústrias indianas. Revista Internacional de Produtividade e Gestão da Qualidade, v. 25, n. 2, p. 212-224. 
PIZONI, R.; SILVA, L. G. P.; PALADINI, E. P. (2018) Economia compartilhada: Gestão da qualidade aplicado a uma empresa do ramo de delivery de comida. Revista Pretexto, v. 19, n. 2, p. 66-75.

QUEIROZ, L. M. A. (2015) Planejamento e controle da manutenção aplicados ao processo de manufatura no ramo alimentício. In: ENCONTRO NACIONAL DE ENGENHARIA DE PRODUÇÃO, 35., 2015, Fortaleza. Anais Eletrônicos... Fortaleza: ABEPRO.

RESOLUÇÃO-RE No 9, de 16 de Janeiro de 2003. https://www.ambientec.com/lei-13-5892018-pmoc-torna-se-obrigatoria-manutencao-de-sistemas-de-ar-condicionado/. Acessado em $03 / 11 / 2018$ as $16: 17$

http://portal.anvisa.gov.br/documents/33880/2568070/RE_09_2003.pdf/f4af80d4-8516-4f9ca745-cc8b4dc15727.

SANTOS, V. A. (2010) Prontuário Para a Manutenção Mecânica. São Paulo: Ícone, 1 ed. SILVA, L. P. (2016) Serviços de Manutenção e Conservação em Instituições de Ensino Superior Privada: Uma análise a Luz do Processo de Pensamento da Teoria das Restrições. Dissertação para obtenção para título de mestre. Programa de Pós-graduação em Engenharia de Produção e Sistemas da Universidade do Vale do Rio dos Sinos- UNISINOS. São Leopoldo.

SLACK, N.; CHAMBERS, S.; HARLAND, C.; HARRISON, A.; JOHNSTON, R. (1997) Administração da Produção. Atlas. São Paulo.

SOURIS, J. P. (1992) Manutenção Industrial - custo ou benefício. Tradução de Elizabete Batista. Lisboa: Lidel.

VIANA, H. R. G.; RIBEIRO, J. L. D. (2017) Fatores de sucesso na gestão da manutenção em empresas mineradoras. Revista Gestão Industrial, v. 13, n. 2.

VILLANUEVA, M. M. (2015) A importância da manutenção preventiva para o bom desempenho da edificação. Trabalho de Conclusão de Curso para obtenção do grau de Engenheira Civil. Universidade Federal do Rio de Janeiro. Rio de Janeiro.

WIREMAN, T. (1998) Developing Performance Indicators for Managing Maintenance. Nova York: Industrial Press.

WAKCHAURE, V. D.; VENKATESH, M. A.; KALLURKAR, S. P. (2006) Review of JIT practices in Indian manufacturing industries. In 2006 IEEE International Conference on Management of Innovation and Technology, IEEE, v. 2, p. 1099-1103.

XENOS, H. G. P. (2004) Gerenciando a Manutenção Produtiva. Nova Lima: Editora Falconi. 